\title{
PERFORMANCE DAS HISTÓRIAS: TESTEMUNHOS TARDIOS (LUCIANO DE SAMÓSATA, HERÓDOTO OU AÉCION)
}

\author{
TATIANA RIBEIRO \\ Universidade Federal do Rio de Janeiro
}

Resumo. Proposta de tradução de Heródoto ou Aécion, de Luciano de Samósata. Palavras-chave. Luciano; Heródoto; historiografia; performance; epídeixis. D.o.I. 10.11606/issn.2358-3150.v19i1p196-200

TESTEMUNHOS TARDIOS JÁ FORAM SUPERVALORIZAdOS - POR UMA PROXImidade maior com a época de Heródoto, o que mais tarde pareceu sem nenhum sentido - e também menosprezados - por não poderem mesmo acrescentar dados a uma perspectiva histórica que visa à "reconstituição". Eles são, no entanto, não somente um importante depoimento da recepção a partir de autores que usavam habitualmente a língua de Heródoto e que conheciam ao menos vestígios do que poderiam ter sido suas apresentações, mas também uma abordagem que conta com o cruzamento de dados escritos de que não dispomos mais.

Apesar de não haver nenhum escrito datado do século $\mathrm{V}$ que nos sirva de documento acerca de leituras públicas das Histórias, a imagem de um Heródoto recitador, quiçá cantor, de suas narrativas nos é apresentada por um autor distante alguns séculos do Historiador: Luciano de Samósata, um dos principais representantes da Segunda Sofística (séc. II d.C). Em uma de suas prolaliai ${ }^{1}$, Luciano compõe um Heródoto que se faz digno de imitação não só pela beleza de seus discursos e a grandeza de suas gnômai, mas sobretudo por sua capacidade estratégica de, em pouco tempo, em um instante bastante específico, ter levado ao conhecimento de todos os gregos

\footnotetext{
• Doutora em Letras Clássicas pela Universidade Federal do Rio de Janeiro (2010).

"* Artigo recebido em 15.out.2016 e aceito para publicação em 28.dez.2016.

${ }^{1}$ Prolaliá era, nos textos da segunda sofística, uma breve peça de retórica epidítica, introdutória às declamações. As prolaliaí nem sempre mantinham estreita afinidade temática com o tema do discurso a que antecedia, sendo, antes, um exercício retórico, no qual se revelava a habilidade do orador, que deste modo preparava os ouvidos de sua audiência.
} 
o seu vasto escrito. Em Heródoto ou Aécion, Heródoto é apresentado como um recitador nos Festivais Olímpicos. Eis minha proposta de tradução para o texto de Luciano. ${ }^{2}$

\section{$*$}

1. Quisera fosse possível imitar também as outras características de Heródoto. Não falo de todas as que lhe são próprias (pois isso seria mais do que um desejo), mas de todas elas uma única: a beleza dos discursos ou arranjo desses, ou o que é próprio e natural da Jônia, a grandiosidade de seu pensamento ou ainda todas as miríades de belezas que ele, em um todo, combina, para além da esperança da imitação. Mas o que ele fez com seus escritos e como, em pouco tempo, se tornou muito valoroso para todos os gregos, isso eu, tu e outros poderíamos imitar.

Tendo navegado, de sua casa, na Cária, rumo à Grécia, pensava consigo mesmo como poderia, mais rápido e facilmente, tornar-se insigne e reconhecido, ele e também sua obra. Ler, viajando de um lugar a outro, ora para atenienses, ora para coríntios, argivos ou lacedemônios separadamente, julgava ser trabalhoso e demorado e que o tempo despendido nisso não seria pouco. Certamente não lhe parecia conveniente dividir a ação nem acumular e reunir aos poucos o reconhecimento de acordo com sua distinção, mas planejava, se fosse possível, tomar todos os gregos conjuntamente. Realizam-se então os grandes jogos Olímpicos, e Heródoto, considerando que lhe chegara o momento por que tanto ansiava, observando a panegíria lotada, de todas as partes os mais distintos homens já reunidos, tendo-se aproximado da parte de trás do templo, não como espectador, mas como competidor dos Jogos Olímpicos ${ }^{3}$, apresentava-se cantando ${ }^{4}$ suas Histórias e encantando os presentes, a ponto de seus livros terem recebido o nomes das Musas, sendo eles também nove.

\footnotetext{
Apresento aqui uma nova versão da tradução proposta em minha Tese de Doutorado. Cf. Ribeiro 2010.

${ }^{3}$ Salta aos olhos, nesse escrito, a afirmativa de que esse Heródoto elege a panegíria dos Jogos Olímpicos como ocasião ideal para a divulgação abrangente de sua obra. O "ler viajando" (tò

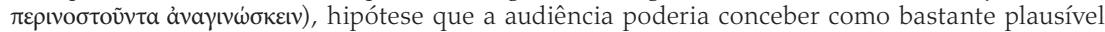
dada a própria natureza do trabalho de Heródoto, pesquisador-viajante, é descartado por Luciano, que tem a apresentação do Historiador nos Jogos Olímpicos como um modelo comparativo para sua própria epídeixis diante da assembleia macedônica.

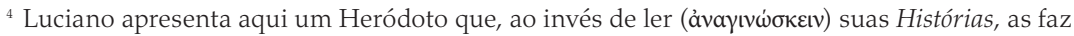
conhecer cantando-as (ạֵ $\delta \omega v)$. O Heródoto de Luciano não é um espectador, mas um ả $\gamma \omega v i \sigma \tau \eta \dot{~ s, ~}$

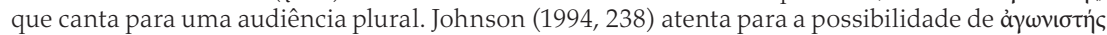
significar não somente um competidor nos jogos, mas sobretudo um "crowd-pleaser", alguém que agrada multidões.
} 
2. Então todos já o conheciam muito mais do que os próprios vencedores olímpicos. E não há quem não tenha ouvido o nome de Heródoto - uns o tendo ouvido, eles próprios, em Olímpia; outros, tendo tomado conhecimento pelos que vieram do festival. E, se ele simplesmente aparecesse, apontavam com o dedo: "Esse é aquele Heródoto, o que escreveu em jônico acerca dos combates persas, o que celebrou nossas vitórias". De suas Histórias ele tirou tais proveitos, tendo alcançado, em um único encontro, todos os povos e o voto unânime da Grécia, tendo sido aclamado não por um único arauto, por Zeus!, mas em toda cidade, de onde cada um era espectador dos festivais.

3. Tendo compreendido, mais tarde, que esse era um curto caminho para o reconhecimento, Hípias, o sofista dessa cidade, Pródico de Céos, Anaxímenes de Quios, Polo de Agrigento e outros tantos faziam sempre, eles próprios, discursos diante da panegíria, e por esses tornaram-se conhecidos em pouco tempo.

4. E por que te falo daqueles antigos sofistas, historiadores, logógrafos, quando enfim dizem isso de Aécion, o pintor que representou as bodas de Roxana e Alexandre, tendo ele próprio levado a imagem a Olímpia para apresentá-la, de sorte que Proxênides, então juiz dos jogos olímpicos, deleitado com a arte de Aécion, fez dele seu genro?

5. Mas o que de admirável havia em sua pintura, perguntou alguém, para que o juiz dos jogos, por isso, desse a filha em casamento a um não conterrâneo como Aécion? A imagem está na Itália, e eu a vi, de sorte que também poderia lhe falar dela ${ }^{5}$. Há um aposento muito belo e um leito nupcial, e Roxana está sentada, uma preciosa donzela, de olhos ao chão, acanhada diante de Alexandre, que está de pé. Há alguns Cupidos sorrindo; o que está colocado acima, por trás, retira o véu da cabeça e mostra ao noivo Roxana, enquanto outro, mui servilmente, tira-lhe a sandália do pé, como se

\footnotetext{
${ }^{5}$ Luciano faz, a partir desse trecho, uma descrição ecfrástica da pintura de Aécion, que é parte

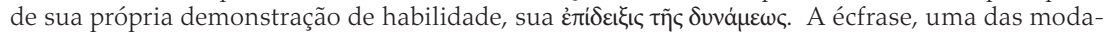
lidades do discurso epidítico praticada como exercício de eloquência, é definida por Hermógenes nos Progymnasmata, como 'um enunciado que apresenta em detalhe, como dizem os teóricos, que tem a vividez e que põe sob os olhos o que mostra' (apud Hansen 2006, 103). Esse 'apresentar a coisa quase como se o ouvido a visse em detalhe', de acordo com a metáfrase de Hansen, é uma experiência que também faz evocar um caráter do discurso herodotiano. Como já assinalara Burguess $(1902,200)$, a écfrase é um dos tópoi da literatura epidítica que está presente também em Heródoto, na descrição dos animais do Egito, da Babilônia. E essa parece ter sido uma percepção comum entre os antigos, se pensarmos no que diz o Pseudo-Longino em seu tratado De sublimitate (26.2): “E Heródoto (diz), mais ou menos, assim: 'A partir da cidade de Elefantina, navegarás rio acima e, em seguida, chegarás a uma planície lisa; após ter atravessado essa região, de novo pegarás uma outra embarcação e navegarás dois dias; em seguida chegarás a uma grande cidade, cujo nome é Méroe.' Vês, meu amigo, como ele pega tua alma e a leva através dos lugares, fazendo da audição a visão? Todas as coisas dessa espécie, quando se dirigem às próprias pessoas, conduzem o ouvinte diante dos próprios acontecimentos." (Tradução de Filomena Hirata)
} 
ela já se deitasse; um outro, este também Cupido, toma o manto de Alexandre, puxa-o para Roxana com toda força, esticando-o. O próprio rei dá uma coroa à jovem, e Hefestion, padrinho e ninfagogo, também se faz presente, com uma tocha de pinho incandescente, apoiando-se em um jovem bem na flor da idade - suponho que é Himeneu (pois o nome não está inscrito). No outro lado da imagem, outros Cupidos brincam com as armas de Alexandre, dois com sua lança, imitando os carregadores quando sobre eles pesa uma viga; outros dois arrastam um terceiro deitado sobre o escudo, o próprio rei eu suponho, segurando as alças do escudo. E ainda um outro, dentro de uma couraça colocada na parte inferior, parece estar de tocaia, a fim de assustá-los, quando, por ele, estiverem a arrastar o escudo.

6. Isso não consiste em simples brincadeira, nem Aécion empregou esforço vão nisso, mas evidencia também o amor de Alexandre pelas coisas de guerra; que, enquanto amava Roxana, não se esquecia das armas. Aliás, esta imagem revela claramente algo que diz respeito às núpcias de verdade, tendo despertado os amores da filha de Proxênides por Aécion. Ele partiu casado, feito decorrente da (imagem) das núpcias de Alexandre, sob a proteção do rei ninfagogo, tendo recebido, como pagamento do casamento representado, um casamento verdadeiro.

7. Então, Heródoto (volto a ele) considerou adequada a panegíria dos jogos olímpicos para mostrar aos gregos um admirável historiador, que relatou as vitórias gregas, conforme ele as narrou ${ }^{6}$. Eu - por Zeus, protetor da amizade!, não penseis que deliro como um coribante nem que comparo minha obra às dele; o homem é especial! - afirmo que se passa comigo algo semelhante com ele. Pois, quando estive na Macedônia pela primeira vez, ponderava comigo mesmo sobre o que me haveria de ser proveitoso nessa circunstância. Era esse o desejo: ser conhecido por todos vós e também mostrar minha obra ao maior número possível de macedônios. Mas estar em cada cidade, visitando-as pessoalmente nessa época do ano, não parecia fácil; se eu atentasse para esse vosso encontro, e então, vindo para o meio de vós, mostrasse meu discurso, como deve ser, assim minhas preces se cumpririam.

\footnotetext{
${ }^{6}$ Como sublinha François Hartog $(1999,285)$, ajunta-se à tradição de um Heródoto meio sofista, meio rapsodo, ao mesmo tempo declamador e expositor, um provérbio que diz: "à sombra de Heródoto: sobre os que não concluíram o que propuseram". Esse provérbio, que integra o Corpus Paroemiographorum Graecorum, diz que Heródoto, "logógrafo", adiava sua apresentação das Histórias nos jogos Olímpicos, pois esperava o instante em que houvesse uma sombra no santuário de Zeus. Como o santuário ficava em pleno sol, passado o tempo, "a panegíria então

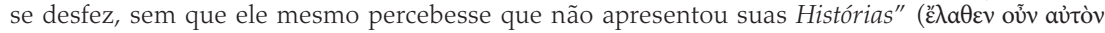

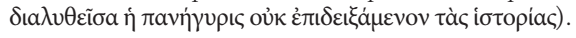


8. Então agora já estais reunidos, a nata de cada uma das cidades, a própria liderança de todos os macedônios, e a cidade que é a melhor me acolhe, não como Pisa, por Zeus!, com seu espaço apertado, e tendas, choupanas, e seu calor sufocante. No entanto, o público desta panegíria não é a turba ignara, que adora contemplar o espetáculo dos atletas, a maioria colocando Heródoto em segundo plano, mas as figuras mais insignes entre rétores e historiadores, bem como entre sofistas - o que já não é pouco, e o meu [discurso] não parece muito mais inferior ao dos jogos Olímpicos. Mas se vós me comparardes a Polidamante, a Glauco ou a Mílon, parecervos-ei por completo um homem arrogante. Mas se olhardes tão somente para mim, desarmados ${ }^{7}$, desviando a lembrança daqueles, prontamente vos pareceria pouco merecedor da chibata! Assim, nesse estádio tão amplo, certamente isso já me é suficiente.

\section{REFERÊNCIAS}

Berkowitz, Luci et al., ed. 2000. "Canon of Greek Authors and Works." In Thesaurus Linguae Graecae (TLG-E). Irvine: University of Carolina.

Burgess, Theodore C. 1902. Epideictic Literature. Chicago: University Chicago Press.

Hansen, João Adolfo. 2006. "Categorias epidíticas da ekphrasis." Revista USP 71: 85-105.

Hartog, François. 1999 [1980]. O espelho de Heródoto. Ensaio sobre a representação do outro. Tradução de Jacyntho Lins Brandão. Belo Horizonte: Ed. da UFMG.

Johnson, William A. 1994. "Oral Performance and the Composition of Herodotus' Histories." Greek, Roman and Byzantine Studies 35(3): 229-54.

Longino. 1996. Do sublime. Tradução Filomena Hirata. São Paulo: Martins Fontes.

Lucian. 1999. How to write history. The Dipsads. saturnalia. Herodotus or Aëtion. Zeuxis or Antiochus. A slip of the tongue in greeting. Apology for the salaried posts in great houses. With an English Translation by K. Kilburn. Cambridge, MA - London: Harvard University Press (Loeb Classical Library, vol. 6).

Ribeiro, Tatiana. 2010. A apódexis herodotiana: um modo de dizer o passado. Tese de Doutorado. Universidade Federal do Rio de Janeiro.

\section{$*$}

Abstract. A translation proposal of Lucian of Samosata's Herodotus or Aëtion.

Keywords. Lucian; Herodotus; historiography; performance; epideixis.

\footnotetext{
${ }^{7}$ Literalmente, "desnudados".
} 